\title{
Valorization of Agricultural Waste: Theoretical Estimation and Experimental Biomethane Yield from Cashew Nut Hulls
}

\author{
Mahamadi Nikiema1,2*, Marius K. Somda1, Joseph B. Sawadogo1,3, Dayéri Dianou ${ }^{4}$, \\ Alfred S. Traoré1, Aboubakar S. Ouattara ${ }^{1}$ \\ ${ }^{1}$ Research Center of Biological, Food and Nutritional Sciences (CRSBAN), Joseph KI-ZERBO University, Ouagadougou, \\ Burkina Faso \\ ${ }^{2}$ Fada N'Gourma University, Fada N'Gourma, Burkina Faso \\ ${ }^{3}$ Nazi BONI University, Bobo Dioulasso, Burkina Faso \\ ${ }^{4}$ National Center of Scientific and Technological Research (CNRST), Ouagadougou, Burkina Faso \\ Email: ${ }^{\star}$ mahamadinikiema87@gmail.com
}

How to cite this paper: Nikiema, M., Somda, M.K., Sawadogo, J.B., Dianou, D., Traoré, A.S. and Ouattara, A.S. (2020) Valorization of Agricultural Waste: Theoretical Estimation and Experimental Biomethane Yield from Cashew Nut Hulls. Journal of Sustainable Bioenergy Systems, 10, 113-130. https://doi.org/10.4236/jsbs.2020.104009

Received: September 23, 2020

Accepted: December 14, 2020

Published: December 17, 2020

Copyright (c) 2020 by author(s) and Scientific Research Publishing Inc. This work is licensed under the Creative Commons Attribution International License (CC BY 4.0).

http://creativecommons.org/licenses/by/4.0/

\begin{abstract}
Biomethane potential production from cashew nut hulls, an agricultural waste, was carried out using old and fresh hulls as substrates. Samples were taken from old hulls (around 8 years old) and fresh hulls produced in cashew scale transformation units at Bobo Dioulasso/Burkina Faso. Physicochemical parameters showed that cashew hulls can be a good candidate for anaerobic digestion. But high acidity, total phenols and lignin tenor could be a constraint for anaerobic bacteria. Theoretical biochemical methane potential showed high value of $666.937 \mathrm{CH}_{4} \mathrm{~L} .(\mathrm{Kg} \mathrm{VS})^{-1}$ and $526.206 \mathrm{CH}_{4} \mathrm{~L} .(\mathrm{Kg} \mathrm{VS})^{-1}$ for crushed fresh and powdered old hulls, respectively. Experimental biochemical methane potential showed significantly low potential of $1.982 \mathrm{CH}_{4}$ L. $(\mathrm{Kg} \mathrm{VM})^{-1}$ and $46.840 \mathrm{CH}_{4} \mathrm{~L}$. $(\mathrm{Kg} \mathrm{VM})^{-1}$ for fresh and hold hulls, respectively. Pretreatment for optimization, chemical composition and co-digestion system must be expected for a better anaerobic digestion performance.
\end{abstract}

\section{Keywords}

Agricultural Waste, Cashew Shells, Anaerobic Digestion, Bio-Energy, Burkina Faso

\section{Introduction}

Cashew trees are grown in tropical regions of the world. The cashew tree occupies an important position among tropical fructiferous trees on account of growing 
commercialization of its main products: nut, cashew nut shell liquid (CNSL), and cashew "apple". Cashew almond is the main commercial product of this tree which can produce around 200 to 300 fruits per year. Cashew production is more concentrated in tropical areas such as Northeast Brazil, West Africa, East Africa, Southeast Asia and islands in southern Indonesia (Figure 1) [1] [2].

The processing of cashew nuts is carried out on large industrial scales in countries such as India, Vietnam and Brazil [2]. However, in many African countries such as Kenya, Mozambique, Tanzania, Burkina Faso, Nigeria, Benin, Côte d'Ivoire and Guinea-Bissau, the cashew nut transformation takes place either on small industrial or semi-industrial scales. In most West African producing countries, there are artisanal transformation units. In Burkina Faso, cashew sector is experiencing an increasingly significant development. The main production provinces are those of Kénédougou and Houet (region), Léraba and Comoé (Cascades region), Poni and Noumbiel (South-West region) and Sissili (Center-West region) with an estimated production of 81,000 tons in 2017 [3].

Processing units, whether large or small, semi-industrial or artisanal, generate $21 \%$ almonds and $79 \%$ consists of $73 \%$ hulls and $6 \%$ dandruff [4]. Thousands of tons of hulls and dandruff are rejected and constitute a source of environmental pollution. Indeed, transformation units store cashew hulls face difficulties accessing energy and managing waste. Hulls and dandruff are burnt to provide energy necessary for weakening of nuts, steaming and drying almonds. This combustion generates significant damage to the environment and human health [5]. In the small scale transformation units of Burkina Faso, this kind of waste can be advantageously used to provide energy necessary for steps of weakening of nuts and drying almonds, particularly energy-consuming processes which generally use unsustainable energy sources such as wood and

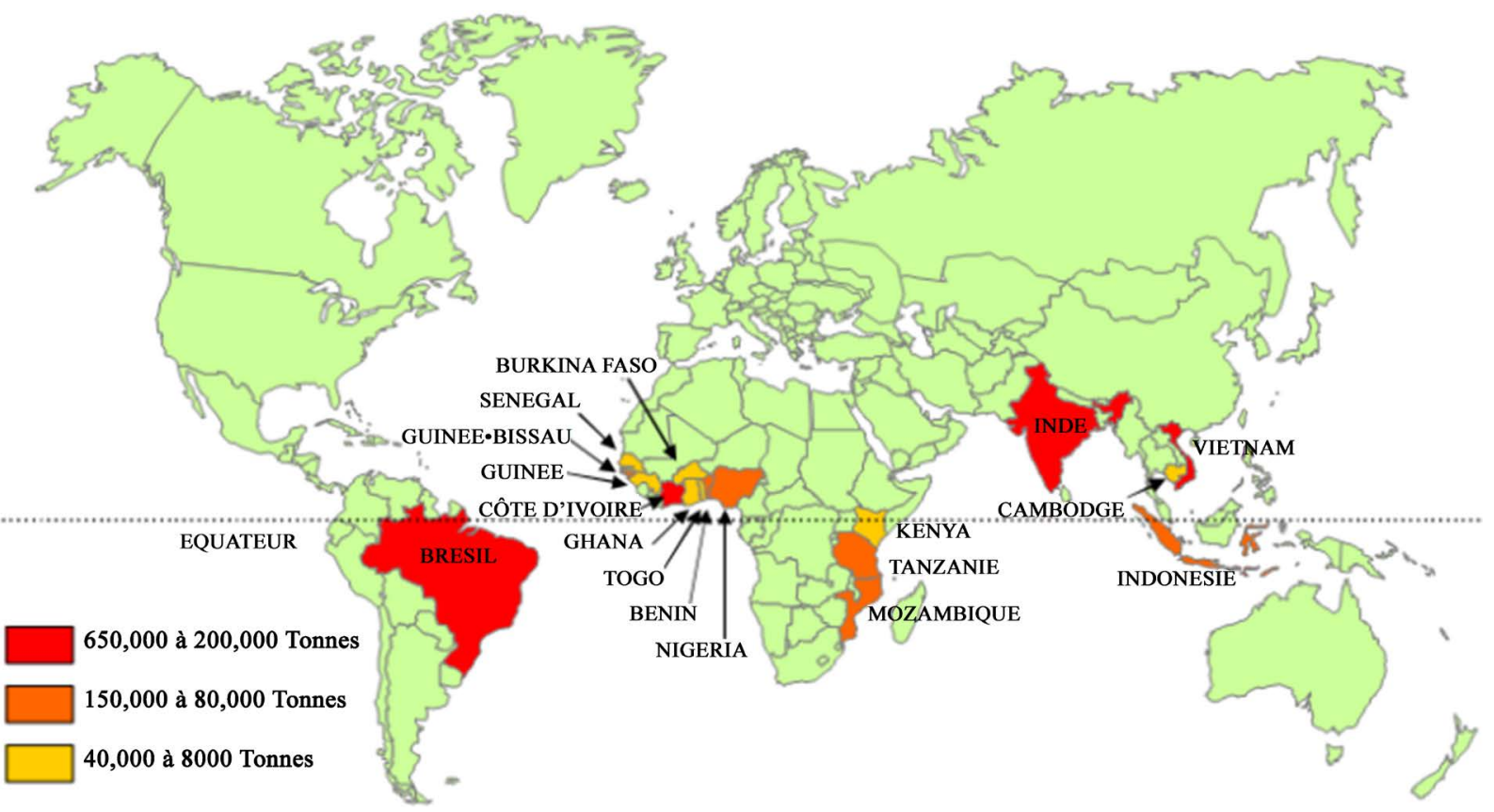

Figure 1. World geographic representation of cashew nut producer (reported by [2]). 
butane gas [6].

Cashew nut consists of a hard woody hull containing cashew nut shell liquid (CNSL). CNSL is composed of 70\% - 90\% anacardic acid, 10\% - 18\% cardol and around 5\% cardanol [7] [8]. Most of the cashew nuts valorization work are oriented towards CNSL extraction processes, some only speaking of thermochemical treatment, in particular pyrolysis and gasification [7] [9] [10]. Wastes (hulls and dandruff) are lignocellulosic compounds, studies showed the possibility to use them in bioenergy (biogas) production. Lignocellulosic substrates include woody substrates such as hardwood and softwood, agricultural residues, dedicated energy crops, weeds and municipal solid waste. Structure and components of weed cell walls are significantly different from that of most plant species, which can influence digestibility during bioconversion process [11] [12]. The possibility to use agro-wastes like coconut oil cake, cashew apple waste, and grass from lawn cuttings in anaerobic digestion was demonstrated [13]. The anaerobic digestion of cashew bagasse was experimented, but no conclusive result was found due to the complexity of this substrate [14]. No study has currently been carried out on use of cashew hulls in anaerobic digestion given complexity of this new substrat. The presence of certain substances including anacardic acids, cardol and cardanol could constitute a limit to the bioconversion of cashew shells into biogas. The objective of this study is to determine physicochemical composition of cashew hulls in order to estimate biomethane potential and to consider various treatments suitable for an application.

\section{Materials and Methods}

\subsection{Sampling and Preparation of Cashew Hulls}

Sampling was carried out on the site of ANATRANS, a high scale transformation unit of cashew, located to Bobo-Dioulasso, in Burkina Faso, West Africa. Two types of waste sample were used: eight-year-old hulls $(\mathrm{OH})$ and fresh hulls (FH) freshly produced. Old hulls samples were ground to particles with a diameter of $1.0 \mathrm{~mm}$ while fresh hulls were justly crushed, as shown in Figure 2 .

\subsection{Chemical Analysis}

\subsection{1. $\mathrm{pH}$ and Acidity}

The $\mathrm{pH}$ was determined according to method described by [15]. Five gram (5 g) of powdered old hulls and crushed fresh hulls was homogenized in $45 \mathrm{~mL}$ of distilled water. $\mathrm{pH}$ meter (WTW $\mathrm{pH} 340$ ) previously calibrated with buffer solutions at $25^{\circ} \mathrm{C}$ was used for measurement. Ten gram $(10 \mathrm{~g})$ of sample were diluted into $90 \mathrm{~mL}$ distilled water. Solution was used for titration of lactic acidity (in triplicate) with $0.1 \mathrm{~N}$ sodium hydroxide until a stable $\mathrm{pH}$ of 8.50 is obtained. Acidity was calculated according to [15] and confirmed by direct titration of $\mathrm{NaOH} 0.1$ $\mathrm{N}$ with phenolphthalein indicator as follows Equation (1).

$$
\operatorname{Acidity}(\%)=\frac{N \times V \mathrm{NaOH} \times M}{\mathrm{Pe} \times 10}
$$




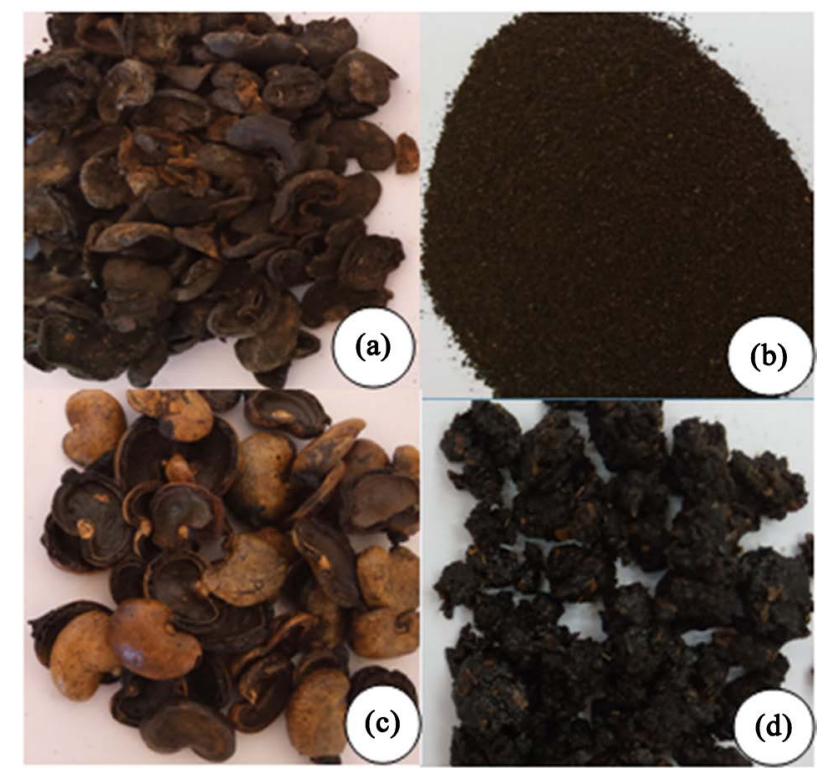

Figure 2. Photograph showing condition of two types of sample of cashew hulls: (a) Old hulls; (b) Powdered old hulls; (c) Fresh hulls; (d) Crushed fresh hulls.

where: $N$ : Normality of $\mathrm{NaOH}(0.1 \mathrm{~N}), V \mathrm{NaOH}$ : Volume of $\mathrm{NaOH}$ to have turn $(\mathrm{mL}), M$ : Anacardic acid molecular weight $(342.4718 \mathrm{~g} / \mathrm{mol})$, Pe: Test sample in grams (5 g), 10: $\mathrm{g}$ of acid per $1000 \mathrm{~g}$ of sample.

\subsubsection{Determination of Total and Volatile Solids}

Total and volatile solids contents were determined according to [16], implemented in analysis of soils reported by [17]. Total solid content (TS) was determined by drying $5 \mathrm{~g}$ sample in an oven at $105^{\circ} \mathrm{C}$ until a constant weight is obtained. Volatile solid (VS) content was obtained by weight difference between dried waste and waste burned at $550^{\circ} \mathrm{C}$ for 4 hours.

\subsubsection{Determination of Total Phenols}

Adapted method described by [18] using 1:5 ratio (w/v) was used. One gram (1 g) of defatted hulls samples was macerated in a closed $50 \mathrm{ml}$ bottle containing 10 $\mathrm{ml}$ mixture of methanol $(80 \%)$ and water $(20 \%)$ on a magnetic stirrer at room temperature. After $24 \mathrm{~h}$, the mixture was centrifuged at $1000 \mathrm{~g}$ and supernatant was used for phenols assay. Total phenols were estimated by [19] method reported by [20]. Fifty microliters $(50 \mu \mathrm{l})$ of Folin-Ciocalteu reagent (FCR) $(0.2 \mathrm{~N}$ in distilled water) was mixed with $10 \mu \mathrm{l}$ of shells extract $(0.1 \mathrm{mg} / \mathrm{mL})$ in a 96-well plate. Five minutes $(5 \mathrm{~min})$ incubation, $40 \mu \mathrm{l}$ of $\mathrm{Na}_{2} \mathrm{CO}_{3}(75 \mathrm{~g} / \mathrm{L})$ is added to the previous mixture. The mixtures were kept at room temperature in the dark for 2 h. Absorbances were then read at $760 \mathrm{~nm}$ using a BioteckEpoch spectrophotometer UV (CECIL CE 2041, Cambridge, England). Phenols contents extracts were determined from regression equation $\left(\mathrm{Y}=0.014 \mathrm{X}+0.145 ; \mathrm{R}^{2}=0.997\right) \mathrm{ob}-$ tained from a dilution range of gallic acid in water. Three tests were carried out, and the result was expressed in milligrams of gallic acid equivalent per $1 \mathrm{~g}$ of extract $\left(\mathrm{mg} \mathrm{GAE} \cdot \mathrm{g}^{-1}\right)$. 


\subsubsection{Determination of Macromolecules}

Lipid content was determined according to Soxhlet extraction method using hexane as solvent [21]. The balloons were washed and dried. Empty weight of balloons was determined. Five grams (5 g) of waste powder were introduced into extraction cartridges which were closed with cotton and placed in Soxhlet. The balloons were filled with approximately $300 \mathrm{~mL}$ hexane and then connected to Soxhlet. The whole was connected to a refrigeration system and was connected to a cryostat to condense solvent vapors intended to entrain the lipids. The extractions lasted $4 \mathrm{~h}$. Hexane was separated from lipids by evaporation on rotary evaporator and flasks were dried at $105^{\circ} \mathrm{C}$. After $1 \mathrm{~h}$, flasks were cooled in desiccators and then weighed.

Total protein content was determined by Kjedahl method as described by [22] reported by [23]. One and half gram (1.5 g) of sample was placed in a flask and $12 \mathrm{~mL}$ sulfuric acid (95\%) and catalyst tablet (Kjeltabs) were added. After hydrolysis step at $400^{\circ} \mathrm{C}$ for $2 \mathrm{~h}$, distillation was performed using Kjeltec apparatus. Ammonia formed will be titrated with sulfuric acid $1 \mathrm{~N}$. Total protein was determined indirectly by a nitrogen-to-protein factor (6.25), $16 \%$ in proteins [24].

Lignin content of biomass samples was determined in accordance with [25] by [26]. Extracted dried biomass after lipid analysis was used. Dried extracted raw biomass $\left(0.3 \mathrm{~g}\right.$ ) was weighed in glass test tubes and $3 \mathrm{~mL} \mathrm{H}_{2} \mathrm{SO}_{4}$ (72\%) was added. Sample was kept at room temperature for $2 \mathrm{~h}$ with carefully shaking at 30 min intervals to hydrolyze and solubilize the carbohydrates. The sample was then diluted with water $(560 \mathrm{~mL}$ to reduce sulphuric acid concentration to $3 \%$ and further boiled for $4 \mathrm{~h}$. Next, lignin is allowed to settle before being filtered. The second step of hydrolysis was made to occur in autoclave at $121^{\circ} \mathrm{C}$ for $1 \mathrm{~h}$. Slurry was then cooled at room temperature. Hydrolyzates were filtered through vaccum using filtering crucible. Acid insoluble lignin was determined by drying the residues at $105^{\circ} \mathrm{C}$ and accounting for ash by incinerating the hydrolyzed samples at $575^{\circ} \mathrm{C}$ in a muffle furnace. Acid soluble lignin fraction was determined by measuring absorbance of acid hydrolyzed samples at $320 \mathrm{~nm}$. Lignin content was calculated as the summation of acid insoluble lignin and acid soluble lignin. Lignin content was calculated as summation of acid insoluble lignin and acid soluble lignin [25] using Equation (2).

$$
\text { Soluble lignin }(\%)=\frac{A}{110} \times \frac{\text { Dilution }}{m(\mathrm{~g})} \times 100 \%
$$

where: $A=$ Absorbance, $m=$ Original sample weight (g).

Combined hemicelluloses and celluloses ( $\mathrm{H} \& \mathrm{C}$ ) content of crude cake representing carbohydrates was estimated by difference according to [27] following Equation (3):

$$
\text { H \& C }(\%)=100 \%-(\% \text { Protein }+\% \text { Lipid }+\% \text { Lignin }+\% \text { Ash })
$$

\subsubsection{Mineral Composition}

Mineral composition was determined by atomic absorption spectrophotometer 
AAS VARIAN $240 \mathrm{FS}$ according to [28]. Waste sample (0.5 g) was used for digestion with wet ashing procedure. Sixteen milliliters $(60 \mathrm{~mL})$ of different acids, $\mathrm{HNO}_{3}-\mathrm{HCl}(3: 1)$ were used for a $0.5 \mathrm{~g}$ sample. Each mixture was heated up to $130^{\circ} \mathrm{C}$ for $4 \mathrm{~h}$ on the hot plate. Then, acid mixtures were added again. After cooling, $5 \mathrm{~mL}$ of distilled water were added to the sample and mixed. The residue was filtered through blue band filter paper. Then sample was diluted to 10 $\mathrm{mL}$ with distilled water. Blank digestions were also carried out in the same way.

\subsection{Theoric Biomethane Potential (TBMP) and Biodegradability}

\subsubsection{Estimation of Theoric Biomethane Potential (TBMP)}

TBMP was determined via the Equation (4) used by [29] [30] study reported by [31]:

TBMP $=($ Lipid $\times 1014+$ Protein $\times 496+$ Carbohydrate $\times 415+$ Lignin $\times 727) \times 0.001$

where: TBMP unit as $\mathrm{CH}_{4} \mathrm{~L}(\mathrm{~kg} \mathrm{VS})^{-1}$, and lipid, protein, carbohydrate and lignin as $\mathrm{g}(\mathrm{kg} \cdot \mathrm{VS})^{-1}$.

\subsubsection{Experimental Biodegradability}

Biochemical methane potential (BMP) of cashew hulls was determined using methods reported by [32] and [13]. The basic medium was prepared by mixing $\mathrm{K}_{2} \mathrm{HPO}_{4}(2 \mathrm{~g})$ and $\mathrm{NH}_{4} \mathrm{Cl}(2 \mathrm{~g})$ in $1000 \mathrm{~mL}$ of distilled water. The media were prepared in $300 \mathrm{ml}$ glass bottles filled to $1 / 3(\mathrm{v} / \mathrm{v})$ according to technique. Four grams ( $4 \mathrm{~g}$ ) of waste were introduced into bottles for a load of $4 \%(\mathrm{w} / \mathrm{v})$. After 3 days pre-fermentation at $37^{\circ} \mathrm{C}, \mathrm{pH}$ was adjusted to 7.0 using $\mathrm{NaHCO}_{3}(10 \%$, $\mathrm{w} / \mathrm{v})$. Then $6 \mathrm{~mL}$ Balch mineral solution was added [33]. The amount of inoculum placed represented $10 \%(\mathrm{v} / \mathrm{v})$ in a final volume of $40 \mathrm{~mL}$. The inoculum was an activated sludge, prepared by mixing wastewater and old reactor sludge according to technique described by [34].

After inoculation, bottle was hermetically sealed with screw caps fitted with a septum to guarantee perfect gas tightness. Anaerobiosis was then carried out in medium by degassing under a flow of nitrogen. Then, bottles were covered with aluminum foil and incubated at $37^{\circ} \mathrm{C}$ for 30 days. A control without substrate was also performed to account for endogenous biogas production from the inoculums. The experiments were carried out in triplicates. A gas chromatograph (Girdel Serie) equipped with a Porapak Q 100/120 column and a thermal conductivity detector was used to determine methane production in the headspace of septum bottles. The temperature of oven and detector in the GC were $60^{\circ} \mathrm{C}$ and $100^{\circ} \mathrm{C}$, respectively. Nitrogen (N50) was used as the carrier gas in GC.

\subsection{Statistical Analyses}

The XLSAT software 2016.02.27444 was used for data statistical analysis. Analysis of variance (ANOVA) was carried out to compare the results obtained from old hulls and fresh hulls using Fisher's tests at probability threshold $\mathrm{p}=5 \%$. 


\section{Results and Discussion}

\subsection{Physicochemical Parameter}

Table 1 presents the physicochemical characteristics of two types of hulls (fresh and old hulls). The $\mathrm{pH}$ of fresh and fold hulls samples was respectively around 4.20 and 6.41. These results agree with those of [35] and [36] on "margines", acid effluents with $\mathrm{pH}$ values between 4.5 and 6 , due to the presence of organic acids (phenolic acids, fatty acids). The $\mathrm{pH}$ is negatively strongly correlated with titratable acidity $(\mathrm{r}=-0.99)$ expressed as a function of anacardic acid. The acidity values were $4.25 \%$ total solids for fresh hulls and $0.38 \%$ total solids for old hulls. Fresh hulls have a significantly higher acidity than those of old hulls $(\mathrm{P}=$ 0.0001). The high acidity of fresh hulls could be explained by the presence of organic acids (phenolic acids, fatty acids). According to [7] [8] reported by [4], CNSL (Cashew Nut Shell Liquid) is an oily substance naturally composed of 70 to $90 \%$ anacardic acid, $10 \%$ to $18 \%$ cardol and about $5 \%$ of cardanol, a rate which increases with the extraction temperature, the anacardic acid decarboxylating into cardanol. Self-oxidation and polymerization reactions phenomena in vegetable transform phenolic alcohols into phenolic acids [35] [37]. In view of these characteristics, it is necessary to find an appropriate pretreatment of hulls before biomethanization and control $\mathrm{pH}$ during process.

Volatile Solids content in fresh hulls $(89.21 \%$ VS) was significantly higher $(\mathrm{P}=$ $0.0001)$ than old hulls one's ( $85.08 \%$ VS). The proportion of volatile solids in mashed fresh hulls was very close to those obtained by [38] and [39]. Indeed,

Table 1. Physical and biochemical characteristics of cashew nut shells sample.

\begin{tabular}{ccccc}
\hline \multirow{2}{*}{ Parameter } & \multicolumn{4}{c}{ Averages } \\
\cline { 2 - 5 } & Units & Fresh hulls & Old hulls & P value \\
\hline pH & - & 4.20 & 6.41 & $<0.0001$ \\
Acidity & \% anacardic acid & 4.25 & 0.38 & $<0.0001$ \\
Total Solid & \% TS & 90.66 & 90.91 & 0.067 \\
Volatile Solid & \% TS & 89.21 & 85.08 & $<0.0001$ \\
Ash & \% TS & 2.18 & 6.07 & $<0.0001$ \\
Lipids & \% TS & 45.91 & 7.91 & 0.002 \\
H\&C & \% TS & 26.95 & 20.83 & 0.182 \\
Protein & \% TS & 3.17 & 8.08 & $<0.0001$ \\
Insoluble Lignin & \% TS & 21.50 & 56.41 & $<0.0001$ \\
soluble Lignin & \% TS & 0.29 & 0.70 & 0.227 \\
Total phenols & mg EAG.g ${ }^{-1}$ TS & 46.95 & 2.79 & $<0.0001$ \\
Nitrogen & \% TS & 0.51 & 1.29 & $<0.0001$ \\
TC & \% TS & 51 & 48.63 & $<0.0001$ \\
C/N & - & 100 & 37.69 & $<0.0001$ \\
\hline
\end{tabular}

H \& C: Hemicelluloses and Cellulose; TC: Total carbon, C/N: Ratio Carbone-Nitrogen. 
92.4\% of dry matter and $85.1 \%$ VS on grasses (turf); $94.9 \%$ TS and $94.8 \%$ VS on wheat straw were found by [38]. Studies on grasses (fodder) showed $88.2 \%$ VS and $95.8 \%$ VS [40]. Work on Calotropis procera leaves, energetically valued for anaerobic biofermentation found $81.43 \%$ VS [39]. High volatile solids values indicate a preferred substrate for anaerobic digestion microorganisms [39] [41]. Biomethane production was directly linked to volatile solid reported by [42]. The concentration and nature of organic matter are decisive for biomethanogenic potential of substrates [41].

Crushed fresh hulls had 26.95\% TS carbohydrate (Hemicellulose and Cellulose), $45.91 \%$ TS lipid and $3.17 \%$ TS protein contents. As for old hulls, contents were $20.83 \%$ TS, $7.91 \%$ TS, $8.08 \%$ TS for carbohydrate (Hemicellulose and Cellulose), lipid and protein, respectively. Protein content from fresh hull in our study was near to that found by [43] (2.32\% TS) and [27] (3.125\% TS). This difference in shells constituents could be due to natural biodegradation of cashew shells in environment through biological processes, physical phenomena, and chemical reactions [44]. Carbohydrate (Hemicellulose and Cellulose) and lignin are elements of major content in agricultural waste. H \& C were $26.95 \%$ and $20.83 \%$ TS for crushed fresh and old hulls, respectively. Results showed a significative different $(\mathrm{p}=0.001)$ with lignin insoluble content in crushed fresh hulls $(21.50 \%)$ and powdered old hulls (56.41\%). Value found in our study was lower than [27] one's which was $27 \%$. Study reported by [45] and [46] found values between $30 \%$ - 40\% for lignin, 25 - 30 for hemicellulose and 25 - 30 for cellulose in nut shells. Generally, lignocellulosic biomass consists of $35 \%-50 \%$ cellulose, $20 \%-35 \%$ hemicellulose, and 10\% - 25\% lignin reported by [47]. Lignin could also be a toxic component for the microorganisms of anaerobic digestion. According to [48], lignin monomers inhibit methanogenic bacteria by $50 \%$ from $2200 \mathrm{mg} \cdot \mathrm{L}^{-1}$. Studies have shown the need for proper pretreatment of substrates containing high proportions of lignin [49] [50] [51]. The ability of basidiomycete fungi to mineralize lignin and faster than other groups of microorganisms was reported by [36].

The $\mathrm{C} / \mathrm{N}$ ratios of the samples were 100 and 39.69 for fresh and old hulls, respectively. $\mathrm{C} / \mathrm{N}$ ratio represents the relationship between the amount of nitrogen and carbon in a feedstock and makes it possible to generally predict the state of equilibrium influencing the digestibility of a substrate [39]. According to [52], [53]; and [54] optimum range of $\mathrm{C} / \mathrm{N}$ ratio for anaerobic digestion is 20-35:1. A low ratio results in increased content of free ammonia that causes high $\mathrm{pH}$ leading to methanogenic inhibition [55]. A high ratio causes rapid depletion of nitrogen causing lower gas production. The values of $\mathrm{C} / \mathrm{N}$ ratio of our samples, in particular old hulls, are suitable for biomethanization, because it is very close to the optimum values according to [54]. The $\mathrm{C} / \mathrm{N}$ ration of crushed fresh hulls samples is high compared to substrates such as nutshell 43.92:1, rice husks $47: 1$, leaves 71.43:1 [56] [57] [58]. Its high values imply the need to carry out codigestion with nitrogen-rich substrates such as livestock effluents. The high lipid 
contents $41.74 \%$ DM contained in the fresh shells could have harmful effects on flora producing biogas. Indeed, studies have shown that long chain fatty acids (LFAs) strongly inhibit bacteria and their toxicity threshold is variable depending on the type of bacteria [59]. The phenomenon of AGLC synergism being very strong according to the same authors, mixtures of AGLC greatly decrease inhibition threshold. Control $\mathrm{pH}$ monitoring was required during anaerobic digestion.

Total phenols had significantly higher contents in fresh hulls $(42.68 \mathrm{mg}$ EAG. $\mathrm{g}^{-1}$ ) compared to old hulls $\left(2.44 \mathrm{mg} \mathrm{EAG} \cdot \mathrm{g}^{-1}\right)$. This decrease in quantity over time would be explained by degradation. Indeed, biodegradation, tannins and anthocyanins polymerization was reported by [60]. The presence of these molecules would be a source of toxicity for anaerobic digestion microorganisms. The antimicrobial margines properties were due to phenol compounds as denoted by [61] [62]. Indeed, the degree of aromatic compounds toxicity depends on their nature and their degree of polymerization. Monomers inhibit methanogenic bacteria by $50 \%$ from $1000 \mathrm{mg} \cdot \mathrm{L}^{-1}$ [63] [35]. These types of substrates are needed for biological pretreatment of upstream from anaerobic digestion. Indeed, several studies have shown the possibility of microorganisms to degrade total phenols [64] [65]. The studies reported by [36] noted a large number of microorganisms have the ability to degrade phenols at low concentrations. These are bacteria such as Rhodopseudomonas satustrisand, Pseudomonas putida [66] [67] [68], fungi Aspergillus niger, Phanerochaete chrysosporium, Aspergillus terreus [64] [65] [69] and yeasts Candida tropicalis [70] [71].

\subsection{Mineral Component of Cashew Hulls}

Table 2 gives ionic composition of hull samples. The results show a significant difference irons contents between powdered old hulls and crushed fresh hulls samples $(\mathrm{P}<0.05)$. This could be explained by possible contaminants that settle on shell over time. Macro-elements such as $\mathrm{Na}^{2+}, \mathrm{Ca}^{2+}$ and $\mathrm{Mg}^{2+}$ contained in hulls are sufficient to stimulate microorganisms' growth [72]. Concentrations of

Table 2. Mineral composition of cashew nut hulls.

\begin{tabular}{cccc}
\hline \multirow{2}{*}{ Mineral } & \multicolumn{2}{c}{ Average $\left[\mathrm{g} \cdot(\mathrm{Kg} \mathrm{TS})^{-1}\right]$} & \multirow{2}{*}{$P$ value } \\
\cline { 2 - 3 } & Fresh hulls & Old hulls & 0.004 \\
$\mathrm{Fe}$ & 0.115 & 0.662 & 0.235 \\
$\mathrm{Na}$ & 0.141 & 0.237 & 0.063 \\
$\mathrm{Ca}$ & 1.117 & 3.157 & 0.007 \\
$\mathrm{Mg}$ & 1.228 & 3.389 & 0.075 \\
$\mathrm{~K}$ & 6.885 & 15.357 & 0.281 \\
$\mathrm{Zn}$ & 0.023 & 0.039 & 0.423 \\
$\mathrm{Cd}$ & 0.0001 & 0.0002 & 0.423 \\
$\mathrm{~Pb}$ & 0.014 & 0.016 & \\
\hline
\end{tabular}


micronutrients $\mathrm{Fe}^{2+}$ can allow development of anaerobic digestion with optimums located respectively between $0.28-50.40 \mathrm{mg} \cdot \mathrm{L}^{-1}$ [73] [74] and [75] reported that $\mathrm{Mg}^{2+}, \mathrm{Ca}^{2+}$ and $\mathrm{Na}^{+}$ions begin to be inhibitors at concentrations of 1000, 2500 and $3500 \mathrm{mg} \cdot \mathrm{L}^{-1}$ respectively. Concentrations of $20 \mathrm{mg} \cdot \mathrm{L}^{-1} \mathrm{zinc}$ caused inhibition $50 \%$ of methane production [76]. Total inhibition of methanogenesis has been observed for concentrations above $100 \mathrm{mg} \cdot \mathrm{L}^{-1} \mathrm{Zinc}$ [77] and $0.1 \mathrm{mg} \cdot \mathrm{L}^{-1}$ of cadmium [78]. These values depend of course on operating conditions inherent in systems studied and vary according to inocula. Mineral concentrations of sample are not limiting and can theoretically stimulate anaerobic digestion. [79] indicated that heavy metals should not cause problems during anaerobic digestion, because the concentration of ions is kept low due to precipitation with sulfites and carbonates.

\subsection{Estimation of Cashew Nut Hulls Biomethane Potential}

Figure 3 shows evolution of biogas production with crushed fresh hulls, powdered old hulls and control (inoculum only). Biogas production increased until the $25^{\text {th }}$ day, and stabilized after $25^{\text {th }}$ day. The average of biogas production was found to be $293.33 \mathrm{~mL}$ and $228.50 \mathrm{~mL}$ for Old and Fresh Hulls, respectively (Figure 3). Control and crushed fresh hulls presented a similar biomethane production (Figure 4). Figure 5 shows the same result with biomethane significantly high

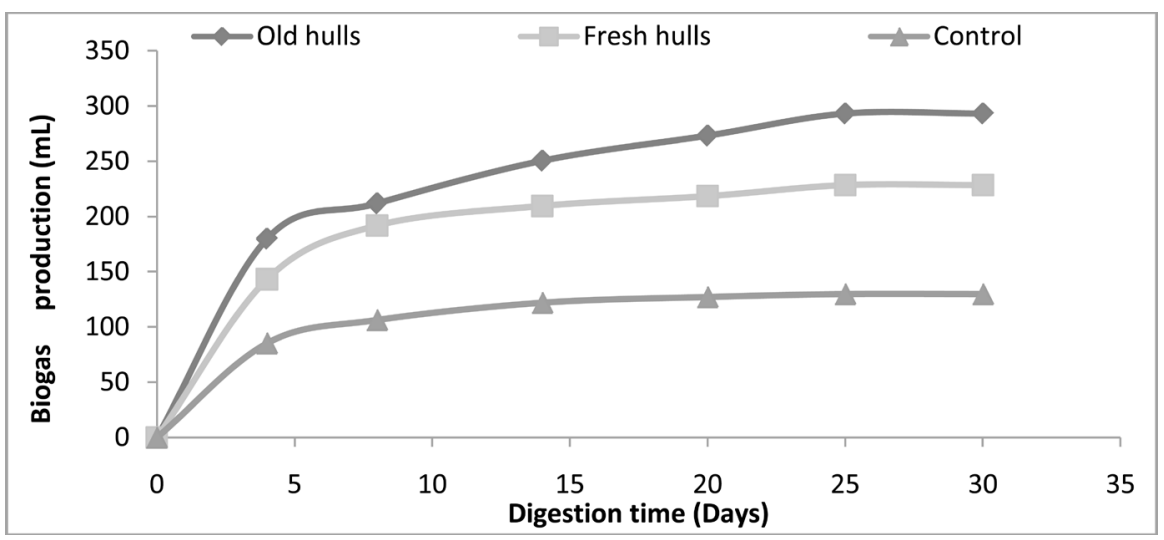

Figure 3. Evolution of biogas production from old and fresh hulls samples.

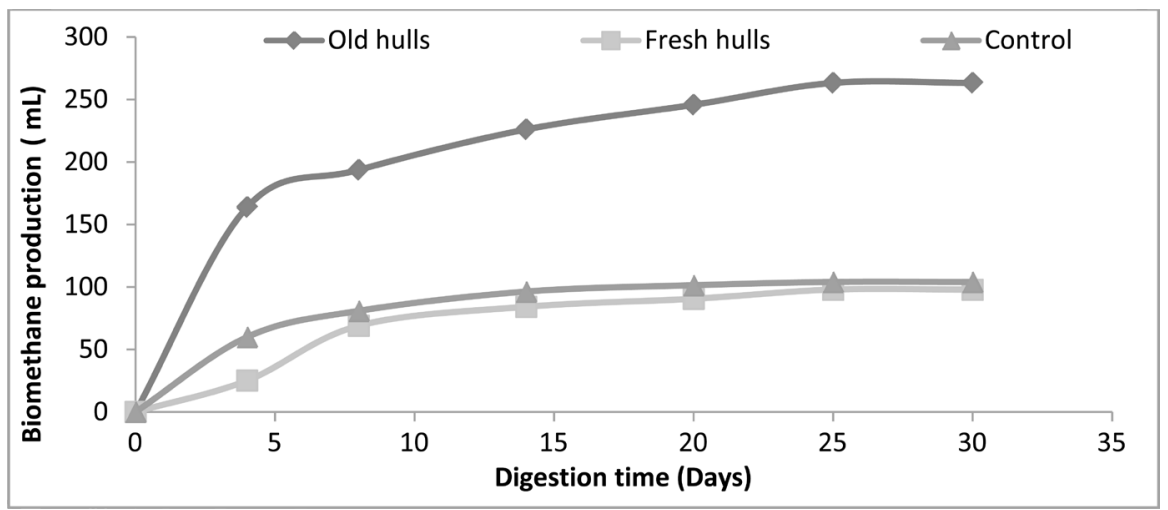

Figure 4. Evolution of biomethane production from old and fresh hulls samples. 


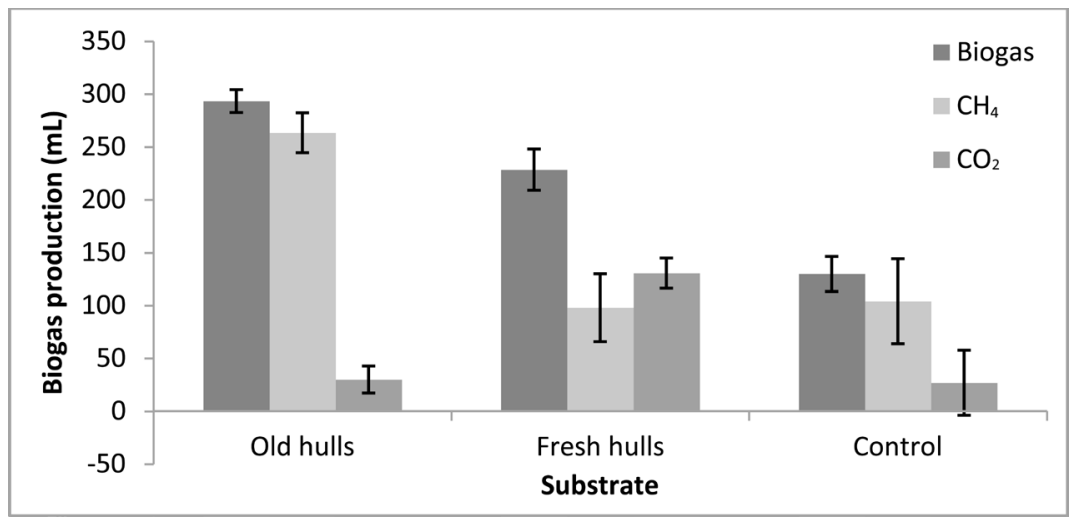

Figure 5. Cumulative biogas, methane $\left(\mathrm{CH}_{4}\right)$ and carbon dioxide $\left(\mathrm{CO}_{2}\right)$ productions for 30 days incubation period.

Table 3. Values of theoretical and experimental potential biochemical methane.

\begin{tabular}{cccc}
\hline \multirow{2}{*}{ Sample } & \multicolumn{2}{c}{ Average $\left(\mathrm{CH}_{4} \mathrm{~L} .(\mathrm{KgVS})^{-1}\right)$} & \multirow{2}{*}{$p$ value } \\
\cline { 2 - 3 } & Old hulls & Fresh hulls & \\
\hline EPBM & 77.400 & 28.760 & 0.002 \\
TBMP & 526.206 & 666.937 & 0.004 \\
\hline
\end{tabular}

TBMP: Theoretical biochemical methane potential; EBMP: Experimental potential biochemical methane.

production with powdered old hulls comparatively to crushed fresh hulls. This result could be explained by inhibition of methanogenic bacteria activity by higher content of CNSL composed of phenolic compounds such as anacardic acid, cardanol, cardol and 2-methylcardol into crushed fresh hulls [80] [81]. The need to develop co-digestion systems seems to be the best option for proper anaerobic digestion of these types of substrates.

Table 3 shows a significant difference between theoretical and experimental values of the biomethane potential of two types of shells used. Biomethane potential was $77.400 \mathrm{CH}_{4} \mathrm{~L} .(\mathrm{KgVS})^{-1}$ and $28.760 \mathrm{CH}_{4} \mathrm{~L} .(\mathrm{KgVS})^{-1}$ for powdered old shell and crushed fresh shell, respectively. The theoretical values were 526.206 $\mathrm{CH}_{4} \mathrm{~L} .(\mathrm{KgVS})^{-1}$ for old shell and $666.937 \mathrm{CH}_{4} \mathrm{~L} .(\mathrm{KgVS})^{-1}$ for crushed fresh hulls. The differences between theoretical and experimental values could be explained by the constraints during anaerobic digestion due to physicochemical composition of substrate. Anacardic acid has an effect on anaerobic digestion bacteria, including a significant reduction in the production of biomethane [81]. Values of $30 \mathrm{~L} / \mathrm{KgTS}$ of biogas were obtained by [14] using cashew apple bagasse as a substrate. [13] found around $140 \mathrm{~L} / \mathrm{KgVS}$ of biogas produced in cashew apple waste anaerobic digestion and methane content was $46 \%$ corresponding to $60.7 \mathrm{~L} / \mathrm{KgVS}$ for 25 days. Cashew nut hulls being more complex than bagasse, this would explain the differences in terms of values.

\section{Conclusion}

Potentialities of cashew nut shells residues as substrates for anaerobic digestion 
have been investigated. Physicochemical parameters of different cashew hulls samples showed substrates that can be used in anaerobic digestion. However, the presence of high-level inhibiting substances such as lignin and total phenols would present risks for methanogenic bacteria. This is observed in the performance of experimental tests which showed a drop in productivity in case of crushed fresh hulls. Optimization of chemical composition of cashew hulls with pretreatment and co-digestion system could be interesting and expected for a better anaerobic digestion performance.

\section{Acknowledgments}

This work was financially supported by a research grant from the International Foundation for Science (IFS_I-3-E-6204-1). Therefore, the authors are grateful to this funding and support of this research.

\section{Conflicts of Interest}

The authors declare no conflicts of interest regarding the publication of this paper.

\section{References}

[1] Ghizzi Gamasceno Da Silva, D. (2011) Fractionnement par voie sèche de la Biomasse Ligno-Cellulosique. Broyage Poussé de la Paille de blé et Effets sur ses Bioconversions. Presse Universitaire du Centre International d'Etudes Supérieures en Sciences Agronomiques, Montpellier, 234 p.

[2] Tall, A. (2013) Amélioration des Qualités Combustibles des Coques d'Anacardiques par l'Utilisation d'un Addititif mEtallique Complexant les Molécules du CNSL. International Institute of Water and Environmental Engineering, Ouagadougou, $61 \mathrm{p}$.

[3] Somé, L.F.M.C. (2014) Analyse Socio-Conomiquedes Systèmes de Production d'Anacarde au Burkina Faso: Cas des Régions des Cascades et des Hauts-Bassins. Université Polytechnique de Bobo Dioulasso, Bobo-Dioulasso, 66 p.

[4] Tagutchou, J. and Naquin, P. (2012) Caracterisation et Traitement Thermochimique des coques d'Anacarde en vue de leur Valorisation énergetique dans les Procédés de Transformation Artisanale de noix de cajou. Déchets Sciences Technologie-Revue Francophonie d Ecologie Industrielle, No. 62, 28-35.

https://doi.org/10.4267/dechets-sciences-techniques.2722

[5] Godjo, T., Tagutchou, J., Naquin, P. and Gourdon, R. (2015) Valorisation des Coques d'Anacarde par Pyrolyse au Bénin. Déchets Sciences Technologie-Revue Francophonie d'Ecologie Industrielle, No. 70, 11-18. https://doi.org/10.4267/dechets-sciences-techniques.3282

[6] Thiombiano, S.T., Weisman, N. and Blin, J. (2011) Adaptation de l'outil Exact et évaluation de l'Empreinte Carbone de la Filière Anacarde au Burkina Faso. 6ème Journées Scientifiques du 2iE, Ouagadougou, du 4-8 Avril 2011, 1-4.

[7] Das, P., Sreelatha, T.D. and Ganesh, A. (2004) Bio Oil from Pyrolysis of Cashew Nut Shell-Characterisation and Related Properties. Biomass and Bioenergy, 27, 265-275. https://doi.org/10.1016/j.biombioe.2003.12.001

[8] Patel, R.N., Bandyopadhyay, S. and Ganesh, A. (2006) Extraction of Cashew (Anacardium occidentale) Nut Shell Liquid Using Supercritical Carbon Dioxide. Biore- 
source Technology, 97, 847-853. https://doi.org/10.1016/j.biortech.2005.04.009

[9] Singh, R.N., Jena, U., Patel, J.B. and Sharma, A.M. (2006) Feasibility Study of cashew Nut Shells as an Open Core Gasifer Feedstock. Renewable Energy, 31, 481487. https://doi.org/10.1016/j.renene.2005.04.010

[10] Tsamba, A.J., Yang, W. and Blasiak, W. (2006) Pyrolysis Characteristics and Global Kinetics of Coconut and Cashew Nut Shells. Fuel Processing Technology, 87, 523530. https://doi.org/10.1016/j.fuproc.2005.12.002

[11] Sakar, S., Yetilmezsoy, K. and Kocak, E. (2009) Anaerobic Digestion Technology in Poultry and Livestock Waste Treatment-A Literature Review. Waste Management and Resarch, 27, 3-18. https://doi.org/10.1177/0734242X07079060

[12] Chandel, A.K. and Singh, O.V. (2011) Weedy Lignocellulosic Feedstock and Microbial Metabolic Engineering: Advancing the Generation of "Biofuel". Applied Microbiology and Biotechnology, 89, 1289-1303. https://doi.org/10.1007/s00253-010-3057-6

[13] Prabhudessai, V., Ganguly, A. and Mutnuri, S. (2013) Biochemical Methane Potential of Agro Wastes. Journal of Energy, 2013, Article ID: 350731.

https://doi.org/10.1155/2013/350731

[14] Leitão, R.C., Claudino, R.L., Freitas de Brito, C.R., Alexandre, L.C., Cassales, A.R., Saavedra, Pinto, G.A. and Santaella, S.T. (2011) Produção de Biogás a Partir do Bagaço do Caju. Embrapa Agroindústria Tropical, Fortaleza, 5-43.

[15] Nout, M.J.R., Rombouts, F.M. and Havelarr, A. (1989) Effect of Accelerated Natural Lactic Fermentation of Infant Food Ingredients on Some Pathogenic Microorganisms. International Journal of Food Microbiology, 8, 351-361. https://doi.org/10.1016/0168-1605(89)90006-8

[16] Association Française de Normalisation (1985) Matières Fertilisantes et Supports de Cultures: Echantillonnage, Analyses Chimiques et Essais Physico-Chimiques. Amendements Organiques et Supports de Culture-Détermination de la Matière Organique Totale-Méthode par Calcination. Association Française de Normalisation, Paris, NF U44-161, 1-4.

[17] Rouez, M. (2008) Dégradation Anaérobie de dEchets Solides: Caractérisation, Facteurs d'Influence et Modélisations. Institut National des Sciences Appliquées, Lyon, $259 \mathrm{p}$.

[18] Wang, L., Lin, X., Zhang, J.C., Zhang, W.M., Hu, X.P., Li, W., Lia, C.F. and Liu, S.X. (2019) Industrial Crops and Products Extraction Methods for the Releasing of Bound Phenolics from Rubus idaeus L. Leaves and Seeds. Industrial Crops \& Products, 135, 1-9. https://doi.org/10.1016/j.indcrop.2019.04.003

[19] Singleton, V.L., Orthofer, R. and Lamuela-Raventos, R.M. (1999) Analysis of Total Phenols and Other Oxidation Substrates and Antioxidants by Means of Folin-Ciocalteu Reagent. Methods in Enzymology, 299, 152-178.

https://doi.org/10.1016/S0076-6879(99)99017-1

[20] Bationo, J.H. (2016) Contribution à l'étude de la Phytochimie et du Potentiel Biologique des Feuilles et des Fruits de Lannea microcarpa Engl \& K. Kraus (Anacardiaceae): Plante médicinale du Burkina Faso. Ouagadougou.

[21] Association Française de Normalisation (1981) Collection of French Standards Body. Fat and Oil Seeds Product. 2nd Edition, Association Française de Normalisation, Paris.

[22] Bremner, J.M. (1965) Total Nitrogen. In: Norman, A.G., Ed., Methods of Soil Analysis. Part 2 Chemical and Microbiological Properties, 9.2, American Society of Agronomy, Wisconsin, 1149-1178. 
[23] Afilal, M.E., Elasri, O. and Merzak, Z. (2014) Caractérisations des Déchets Organiques et évaluation du Potentiel Biogaz (Organic Waste Characterization and Evaluation of Its Potential Biogas). Journal of Materials and Environmental Science, 5, 1160 1169.

[24] Mariotti, F., Tomé, D. and Mirand, P.P. (2016) Converting Nitrogen into ProteinBeyond 6.25 and Jones' Factors. Critical Reviews in Food Science and Nutrition, 48, 177-184. https://doi.org/10.1080/10408390701279749

[25] Sluiter, A., Hames, B., Ruiz, R., Scarlata, C., Sluiter, J., Templeton, D. and Crocker, D. (2008) Determination of Structural Carbohydrates and Lignin in Biomass Laboratory Analytical Procedure (LAP). National Renewable Energy Laboratory, Golden, $1-15$.

[26] Ayeni, A.O., Adeeyo, O.A., Oresegun, O.M. and Oladimeji, E. (2015) Compositional Analysis of Lignocellulosic Materials: Evaluation of an Economically Viable Method Suitable for Woody and Non-Woody Biomass. American Journal of Engineering Research, 4, 14-19.

[27] Melzer, M. (2013) Energetic Valorisation of Agricultural by Products in the Sub-Saharan Zone: Biomass Pre-Conditioning via Flash Pyrolysis. International Institute of Water and Environmental Engineering, University of Technology of Compiègne, Compiègne.

[28] Demirel, S., Tuzen, M., Saracoglu, S. and Soylak, M. (2008) Evaluation of Various Digestion Procedures for Trace Element Contents of Some Food Materials. Journal of Hazard Materials, 152, 1020-1026. https://doi.org/10.1016/j.jhazmat.2007.07.077

[29] Triolo, J.M., Pedersen, L., Qu, H. and Sommer, S.G. (2012) Biochemical Methane Potential and Anaerobic Biodegradability of Non-Herbaceous and Herbaceous Phytomass in Biogas Production. Bioresource Technology, 125, 226-232. https://doi.org/10.1016/j.biortech.2012.08.079

[30] Triolo, J.M., Sommer, S.G., Møller, H.B., Weisbjerg, M.R. and Jiang, X.Y. (2011) A New Algorithm to Characterize Biodegradability of Biomass during Anaerobic Digestion: Influence of Lignin Concentration on Methane Production Potential. Bioresource Technology, 102, 9395-9402. https://doi.org/10.1016/j.biortech.2011.07.026

[31] Pham, C.H., Triolo, J.M., Cu, T.T.T., Pedersen, L. and Sommer, S.G. (2013) Validation and Recommendation of Methods to Measure Biogas Production Potential of Animal Manure. Asian-Australasian Journal of Animal Sciences, 26, 864-873. https://doi.org/10.5713/ajas.2012.12623

[32] Angelidaki, I., Alves, M., Bolzonella, D., Borzacconi, L., Campos, J.L., Guwy, A.J., Kalyuzhnyi, S., Jenicek, P. and van Lier, J.B. (2009) Defining the Biomethane Potential (BMP) of Solid Organic Wastes and Energy Crops: A Proposed Protocol for Batch Assays. Water Science and Technology, 59, 927-934. https://doi.org/10.2166/wst.2009.040

[33] Balch, W.E., Fox, G.E., Magrum, L.J., Woese, L.R. and Wolfe, R.S. (1979) Methanogens: Reevaluation of a Unique Biological Group. Microbiology and Molecular Biology Reviews, 43, 260-296. https://doi.org/10.1128/MMBR.43.2.260-296.1979

[34] Nikièma, M., Somda, M.K., Adéoti, K., Traoré, D., Baba-moussa, F., Toukourou, F., Dianou, D. and Traoré, A.S. (2017) Optimization of Biogas Production from Organic Municipal Waste: Development of Activated Sludge as Digesters Inoculum. Journal of Environmental Protection, 8, 1674-1687. https://doi.org/10.4236/jep.2017.813103

[35] Hamdi, M. (1991) Nouvelle Conception d'un Procédé de Dépollution Biologique 
des Margines, Effluents Liquides de l'Extraction de l'Huile d'Olive. Université de Provence Aix-Marseille, Provence.

[36] Aissam, H. (2013) Etude de la Biodégradation des Effluents des Huileries (Margines) et leur Valorisation par Production de l'Enzyme Tannase. Université Idi Mohamed Ben Abdellah, Fez.

[37] Assas, N., Ayed, L., Marouani, L. and Hamdi, M. (2002) Decolorization of Fresh and Stored and Stored-Black Olive Mill Wastewaters by Geotrichum candidum. Process Biochemistry, 38, 361-365. https://doi.org/10.1016/S0032-9592(02)00091-2

[38] Veeken, A. and Hamelers, B. (1999) Effect of Temperature on Hydrolysis Rates of Selected Biowaste Components. Bioresource Technology, 69, 249-254.

https://doi.org/10.1016/S0960-8524(98)00188-6

[39] Milaiti, M., Traoré, A.S. and Moletta, R. (2003) Essais de Fermentation à Partir de Calotropis Procera Production de $\mathrm{CH}_{4}$ en Fonction de la Charge en Substrat et en Fonction de la Température. Sciences et Médecine, 2, 73-78.

[40] Tong, X.G., Smith, L.H. and McCarty, P.L. (1990) Methane Fermentation of Selected Lignocellulosic Materials. Biomass, 21, 239-255.

https://doi.org/10.1016/0144-4565(90)90075-U

[41] Møller, B.H., Sommer, S.G. and Ahring, B.K. (2004) Methane Productivity of Manure, Strawand Solid Fractions of Manure. Biomass and Bioenergy, 26, 485-495. https://doi.org/10.1016/j.biombioe.2003.08.008

[42] Moody, L.R., Burns, R., Wu-Haan, W. and Spajić, R. (2009) Use of Biochemical Methane Potential (BMP) Assays for Predicting and Enhancing Anaerobic Digester Performance. Proceedings of the 4th International and 44th Croatian Symposium of Agriculture, Optija, 16-20 Februry 2009, 466.

[43] Stamford, T.L.M., Vieira, R., Guerra, N.B., De Medeiros, R.B. and Cavalcante, M.L. (1988) Protein Enrichment of Cashew Wastes for Animal Feeds. Food Science, 10, 1-4. https://doi.org/10.1177/156482658801000102

[44] Joutey, N.T., Bahafid, W., Sayel, H. and El Ghachtouli, N. (2013) Biodegradation: Involved Microorganisms and Genetically Engineered Microorganisms. In: Chamy, R. and Rosenkranz, F., Eds., Biodegradation-Life of Science, IntechOpen, London, 290-320.

https://www.intechopen.com/books/biodegradation-life-ofscience/biodegradation-i nvolved-microorganisms-and-genetically-engineered-microorganisms\#B4

[45] Anwar, Z., Gulfraz, M. and Irshad M. (2014) Agro-Industrial Lignocellulosic Biomass a Key to Unlock the Future Bio-Energy: A Brief Review. Journal of Radiation Research and Applied Sciences, 7, 163-173. https://doi.org/10.1016/j.jrras.2014.02.003

[46] Howard, R.L., Abotsi, E., Jansen van Rensburg, E.L. and Howard S. (2003) Lignocellulose Biotechnology: Issues of Bioconversion and Enzyme Production. African Journal of Biotechnoly, 2, 602-619. https://doi.org/10.5897/AJB2003.000-1115

[47] Isikgor, F.H. and Becer, C.R. (2015) Polymer Chemistry the Production of Bio-Based Chemicals and Polymers. Polymer Chemistry, 6, 4497-4559. https://doi.org/10.1039/C5PY00263I

[48] Benjamin, M.M., Wood, S.L. and Ferguson, J.F. (1984) Anaerobic Toxicity and Biodegradability of Pulpmill Waste Constituents. Water Research, 18, 601-607. https://doi.org/10.1016/0043-1354(84)90210-0

[49] Krishania, M., Kumar, V., Vijay, V.K. and Malik, A. (2013) Analysis of Different Techniques Used for Improvement of Biomethanation Process: A Review. Fuel, 
106, 1-9. https://doi.org/10.1016/j.fuel.2012.12.007

[50] Zheng, Y., Zhao, J., Xu, F.Q. and Li, Y.B. (2014) Pretreatment of Lignocellulosic Biomass for Enhanced Biogas Production. Progress in Energy and Combustion Science, 42, 35-53. https://doi.org/10.1016/j.pecs.2014.01.001

[51] Yu, H.T., Chen, B.Y., Li, B.Y., Tseng, M.C., Han, C.C. and Shyu, S.G. (2018) Efcient Pretreatment of Lignocellulosic Biomass with High Recovery of Solid Lignin and Fermentable Sugars Using Fenton Reaction in a Mixed Solvent. Biotechnoly for Biofuels, 11, Article No. 287. https://doi.org/10.1186/s13068-018-1288-4

[52] Charnay, F. (2005) Compostage des Déchets Urbains dans les Pays en Développement: Elaboration d'une Démarche Méthodologique Pour une Production Pérenne de Compost. Université de Limoges, Limoges.

[53] Wang, S.J., Hou, X.C. and Su, H.J. (2017) Exploration of the Relationship between Biogas Production and Microbial Community under High Salinity Conditions. Scientific Reports, 7, Article No. 1149. http://www.nature.com/articles/s41598-017-01298-y

[54] Kwietniewska, E. and Tys, J. (2014) Process Characteristics, Inhibition Factors and Methane Yields of Anaerobic Digestion Process, with Particular Focus on Microalgal Biomass Fermentation. Renewable and Sustainable Energy Reviews, 34, 491-500. https://doi.org/10.1016/j.rser.2014.03.041

[55] Khalid, A., Arshad, M., Anjum, M., Mahmood, T. and Dawson, L. (2013) Review: The Anaerobic Digestion of Solid Organic Waste. Waste Management, 31, 1737-1744. https://doi.org/10.1016/j.wasman.2011.03.021

[56] Dioha, I.J., Ikeme, C.H., Nafi'u, T., Soba, N.I. and Yusuf, M.B.S. (2013) Effect of Carbon to Nitrogen Ratio on Biogas Production. International Research Journal of Natural Science, 2, 30-39.

[57] Zhou, H., Meng, A., Long, Y.Q., Li, Q.H. and Zhang, Y.G. (2014) Classification and Comparison of Municipal Solid Waste Based on Thermochemical Characteristics. Journal of the Air \& Waste Management Association, 64, 597-616. https://doi.org/10.1080/10962247.2013.873094

[58] Jingura, R.M. and Kamusoko, R. (2017) Methods for Determination of Biomethane Potential of Feedstocks: A Review. Biofuel Research Journal, 4, 573-586. https://doi.org/10.18331/BRJ2017.4.2.3

[59] Demeyer, D.L. and Henderickx, H.K. (1967) The Effect of C18 Unsaturated Fatty Acids on Methane Production in Vitro by Mixed Rumen Bacteria. Biochimica et Biophysica Acta-Lipids and Lipid Metabolism, 137, 484-497. https://doi.org/10.1016/0005-2760(67)90130-0

[60] Field, J.A., Lettinga, G. and Habets, L.H.A. (1990) Oxidative Detoxification of Aqueous Bark Extracts. Part I: Autoxidation. Journal Chemical Technology and Biotechnology, 49, 35-53. https://doi.org/10.1002/jctb.280490105

[61] Gonzalez, M.D., Moreno, E., Quevedo-Sarmiento, J. and Ramos-Cormenzana, A. (1990) Studies on Antibacterial Activity of Waste Waters from Olive Oil Mills (alpechin): Inhibitory Activity of Phenolic and Fatty Acids. Chemosphere, 20, 423-432. https://doi.org/10.1016/0045-6535(90)90073-3

[62] Casa, R., D’Annibale, A., Pieruccetti, F., Stazi, S.R., Giovannozzi, S.G. and Lo Cascio, B. (2003) Reduction of the Phenolic Components in Olive-Mill Wastewater by an Enzymatic Treatment and Its Impact on Durum Wheat (Triticum durum Desf.) Germinability. Chemosphere, 50, 959-966. https://doi.org/10.1016/S0045-6535(02)00707-5

[63] Blum, D.J.W., Hergenroeder, R., Parkin, G.F. and Speece, R.E. (1986) Anaerobic 
Treatment of Coal Conversion Wastewater Constituents. Journal Water Pollution Control Federation, 58, 122-131.

[64] Garcia Garcia, I., Jimenez Pena, P., Bonilla Venceslada, J., Martin Martin, A., Martin Santos, M. and Ramos Gomez, E. (2000) Removal of Phenol Compounds from Olive Mill Wastewater Using Phanerochaete chrysosporium, Aspergillus niger, Aspergillus terreus and Geotrichum candidum. Process Biochemistry, 35, 751-758. https://doi.org/10.1016/S0032-9592(99)00135-1

[65] Garrido Hoyos, S.E., Martinez Nieto, L., Camacho, R.F. and Ramos, C.A. (2002) Kinetics of Aerobic Treatment of Olive-Mill Wastewater (OMW) with Aspergillus terreus. Process Biochemistry, 37, 1169-1176.

https://doi.org/10.1016/S0032-9592(01)00332-6

[66] Fountoulakis, M.S., Dokianakis, S.N., Kornaros, M.E., Aggelis, G.G. and Lyberatos, G. (2002) Removal of Phenolics in Olive Mill Wastewaters Using the White-Rot Fungus Pleurotus ostreatus. Water Research, 36, 4735-4744. https://doi.org/10.1016/S0043-1354(02)00184-7

[67] Rahlkar, S.B., Joshi, S.R. and Shivorman, N. (1993) Phototabolism of Aromatic Compounds by Rhodopsudomonas palustris. Current Microbiology, 26, 1-9. https://doi.org/10.1007/BF01577235

[68] Di Gioia, D., Bertin, L., Fava, F. and Marchetti, L. (2001) Biodegradation of Hydroxylated and Methoxylated Benzoic, Phenylacetic and Phenylpropenoic Acids Present in Olive Mill Wastewaters by Two Bacterial Strains. Research in Microbiology, 152, 83-93. https://doi.org/10.1016/S0923-2508(00)01171-2

[69] Bertin, L., Majone, M., Di Gioia, D. and Fava, F. (2001) Anaerobic Fixed-Phase Biofilm Reactor System for the Degradation of the Low-Molecular Weight Aromatic Compounds Occurring in the Effluents of Anaerobic Digestors Treating Olive Mill Wastewaters. Biotechnology Journal, 87, 161-177. https://doi.org/10.1016/S0168-1656(01)00236-X

[70] Chang, S.Y., Li, C., Hiang, S.Y. and Chang, M.C. (1995) Intraspecific Protoplast Fusion of Candida tropicalis for Enhancing Phenol Degradation. Applied Microbiology and Biotechnology, 43, 534-538. https://doi.org/10.1007/BF00218462

[71] Fadil, K., Chahlaoui, A., Ouahbi, A., Zaid, A. and Borja, R. (2003) Aerobic Biodegradation and Detoxification of Wastewaters from the Olive Oil Industry. International Biodeterioration \& Biodegradation, 51, 37-41.

https://doi.org/10.1016/S0964-8305(02)00073-2

[72] Gu, Y., Chen, X., Liu, Z., Zhou, X. and Zhang, Y. (2014) Effect of Inoculum Sources on the Anaerobic Digestion of Rice Straw. Bioresource Technology, 158, 149-155. https://doi.org/10.1016/j.biortech.2014.02.011

[73] Pobeheim, H., Munk, B., Johansson, J. and Guebitz, G.M. (2010) Influence of Trace Elements on Methane Formation from a Synthetic Model Substrate for Maize Silage. Bioresource Technology, 101, 836-839. https://doi.org/10.1016/j.biortech.2009.08.076

[74] Vedrenne, F. (2007) Etude des Processus de Dégradation Anaérobie et de Production de Méthane au Cours du Stockage des Lisiers. Ecole Nationale Supérieure d'Agronomie de Rennes, Rennes.

[75] Rousseau, P. (2009) Etude, Modelisation et Optimisation d'un Procede de Traitement des Lisiers de Porcs par Couplage de la Digestion Anaerobie et du Traitement Biologique de l'azote. Universite de Rennes 1, Rennes.

[76] Zayed, G. and Winter, J. (2000) Inhibition of Methane Production from Whey by Heavy Metals-Protective Effect of Sulfide. Applied Microbiology and Biotechnol- 
ogy, 53, 726-731. https://doi.org/10.1007/s002530000336

[77] Harries, C.R., Scrivens, A., Rees, J.F. and Sleat, R. (2008) Initiation of Methanogenesis in Municipal Solid Waste. 1. The Effect of Heavy Metals on the Initiation of Methanogenesis in MSW Leachate. Environmental Technology, 11, 1169-1175. https://doi.org/10.1080/09593339009384974

[78] Bhattacharya, S.K., Madura, R.L., Uberoi, V. and Haghighi-podeh, M. (1995) Toxic Effects of Cadmium on Methanogenic Systems. Water Research, 29, 2339-2345. https://doi.org/10.1016/0043-1354(95)00066-T

[79] Hickey, R.F., Vanderwielen, J. and Switzenbaum, M.S. (1989) The Effect of Heavy Metals on Sludge, Methane Production and Hydrogen and Carbon Monoxide Levels during Batch Anaerobic Research. Water Research, 23, 207-218. https://doi.org/10.1016/0043-1354(89)90045-6

[80] Watanabe, Y., Suzuki, R., Koike, S., Nagashima, K., Mochizuki, M., Forster, R.J. and Kobayashi, Y. (2010) In Vitro Evaluation of Cashew Nut Shell Liquid as a Methane-Inhibiting and Propionate-Enhancing Agent for Ruminants. Journal of Dairy Science, 93, 5258-5267. https://doi.org/10.3168/jds.2009-2754

[81] Saenab, A., Wiryawan, K.G., Retnani, Y. and Wina, E. (2017) Anacardic Acid Isolated from Cashew Nut Shell (Anacardium occidentale) Affects Methane and Other Products in the Rumen Fermentation. Media Peternakan, 40, 94-100.

https://doi.org/10.5398/medpet.2017.40.2.94 